\title{
STRATEGI MENANGKAL RADIKALISME AGAMA DI KABUPATEN SUMBAWA BARAT
}

\author{
Johan Wahyudi \\ Staf Pengajar Prodi Ilmu Politik, FISIP, Universitas Brawijaya \\ Email: johanwahyudi@ub.ac.id
}

\begin{abstract}
Abstrak
Tingginya penyebaran ideologi radikal di Indonesia menyebabkan adanya potensi dan ancaman penyebaran paham radikal yang semakin menguat ke berbagai daerah. Kabupaten Sumbawa Barat merupakan salah satu daerah potensial penyebaran radikalisme khususnya radikalisme agama, karena adanya beberapa organisasi kemasyarakatan yang memiliki doktrin keagamaan khilafah yang bertentangan dengan Pancasila, sehingga sangat dibutuhkan upaya preventif untuk mengatasinya. Penelitian ini bertujuan untuk mengetahui faktor-faktor apa saja yang berpotensi memicu lahirnya radikalisme agama dan merumuskan strategi menangkal radikalisme agama di Kabupaten Sumbawa Barat. Penelitian ini dilaksanakan di Kabupaten Sumbawa Barat. Pengumpulan data dilakukan dengan menggunakan teknik survei melalui wawancara menggunakan kuesioner penelitian terhadap 30 responden. Metode analisis data yang digunakan yaitu analisis deskriptif dan analisis SWOT untuk mengetahui strategi menangkal radikalisme agama. Hasil penelitian menunjukkan bahwa terdapat 3 faktor yang bisa menjadi pemicu radikalisme agama di Sumbawa Barat; ketidakpuasan terhadap kebijakan pemerintah, lemahnya pengawasan terhadap sekolah yang terindikasi gerakan radikal, serta adanya pemahaman keagamaan yang merasa paling benar dibandingkan kelompok lainnya. Sedangkan strategi untuk menangkal radikalisme agama di Kabupaten Sumbawa Barat dapat dirumuskan strategi S-O (Strengths-Opportunity), yang merupakan strategi yang memanfaatkan kekuatan yang ada untuk merebut peluang.
\end{abstract}

Kata Kunci:

Analisis SWOT, Kabupaten Sumbawa Barat, Radikalisme, Radikalisme Agama

\begin{abstract}
The high spread of radical ideology in Indonesia has led to the potential and threat of spreading radical ideology to various regions. West Sumbawa Regency is one of the potential areas of the spread of radicalism, especially religious radicalism, because there were some social communities that have religious doctrine of the caliphate that contradicts with Pancasila. So it required some preventive efforts to overcome it. This research aims to find out the factors that trigger the rise of religious radicalism in West Sumbawa Regency and find out the efforts and strategies to prevent the entry of radical ideas in West Sumbawa Regency. This research was carried out in West Sumbawa Regency. Data collection was done by survey techniques through interviews using research questionnaires. Interviews were conducted with 30 respondents. The strategy of preventing religious radicalism was formulated using the SWOT analysis method.
\end{abstract}


This study found that at least, there are 3 factors that can trigger religious radicalism in West Sumbawa Regency include; dissatisfaction with government policies, weak government oversight of schools indicated by radical movements, and religious understanding that felt the most right compared to other groups. Based on the findings and analysis results obtained in this study, it can be concluded that the strategy to ward off religious radicalism in West Sumbawa Regency is an $S$-O (Strengths-Opportunity) strategy, which is a strategy that utilizes existing strengths to seize opportunities.

\section{Keywords:}

SWOT Analysis, West Sumbawa Regency, Radicalism, Religious Radicalism

\section{Pendahuluan}

Radikalisme agama merupakan salah satu permasalahan yang terus mengemuka di Indonesia beberapa tahun terakhir. Fenomena ini terus menguat seiring dengan tingginya keterbukaan arus informasi global, media sosial dan semakin masifnya pola rekruitmen yang dilakukan oleh kelompok-kelompok radikal seperti ISIS ataupun kelompok teroris. ${ }^{1}$ Sejak peristiwa Bom Bali tahun 2002, bom di Kedutaan Besar Australia, bom Bali II, bom Thamrin 14 Januari 2016, hingga aksi teor bom di Surabaya 13 Mei 2018 menunjukkan bahwa ancaman radikalisme di Indonesia sangat nyata dan terus terjadi, bahkan ancaman paham radikal telah masuk ke jenjang sekolah dan perguruan tinggi. Temuan survei beberapa lembaga menyebutkan bahwa saat ini paham radikalisme sudah masuk di sekolah di mana sebanyak $21 \%$ siswa dan $21 \%$ guru menyatakan bahwa pancasila sudah tidak lagi relevan digunakan sebagai ideologi bangsa dan pada saat yang sama $84,8 \%$ siswa dan $76,2 \%$ guru lebih setuju dengan penerapan syariat Islam. Selain itu $52,3 \%$ siswa setuju melakukan kekerasan untuk solidaritas agama dan 14,2\% membenarkan aksi pemboman yang dilakukan kalangan radikal. $^{2}$

Selain itu, berdasarkan hasil survei Wahid Foundation bersama Lingkar Survei Indonesia pada 2016 mengungkapkan 11 juta dari 150 juta penduduk muslim Indonesia siap melakukan tindakan radikal. Jumlah tersebut mencapai $7,7 \%$ dari total penduduk muslim Indonesia. Sedangkan 600 ribu atau 0,4\% penduduk muslim Indonesia pernah

\footnotetext{
${ }^{1}$ Bagus Takwin, dkk., Studi tentang Toleransi dan Radikalisme di Indonesia: Pembelajaran dari 4 Daerah Tasikmalaya, Jogjakarta, Bojonegoro dan Kupang (Jakarta: INFID, 2016).

${ }^{2}$ Ahmad Fuad Fanani, "Fenomena Radikalisme di Kalangan Kaum Muda" dalam Jurnal Maarif, Vol. 8, No. 1 (2013), h. 4-7; M. Zaki Mubarak, "Dari Semangat Islam Menuju Sikap Radikal: Pemikiran dan Perilaku Keberagamaan Mahasiswa UIN Syarif Hidayatullah” dalam Jurnal Maarif, Vol. 8, No. 1 (2013), h.192 -217.
} 
melakukan tindakan radikal. ${ }^{3}$ Tidak hanya itu, hasil kajian Lembaga Ketahanan Nasional tahun 2016 menemukan indeks ketahanan nasional di dalam gatra ideologi hanya 2.06 dari skala 1-5, artinya masih masuk dalam kategori "kurang tangguh". Salah satu parameter indeks itu adalah nilai toleransi. Penelitian PPIM UIN Syarif Hidayatullah pada Oktober 2016, sebanyak 78\% responden guru agama dari 5 provinsi setuju jika pemerintah RI dijalankan sesuai syariat Islam dan sebanyak 77\% mendukung organisasi yang memperjuangkan syariat Islam di Tanah Air. ${ }^{4}$ Sementara hasil penelitian terbaru PPIM UIN Jakarta yang bertajuk Survei Nasional: Sikap dan Perilaku Keberagamaan di Sekolah dan Universitas yang dipublikasikan tahun 2018 menemukan bahwa pandangan keagamaan siswa dan mahasiswa pada level sikap atau opini yang cenderung radikal berada di angka 58,5\%, intoleransi internal 51,1\% dan intoleransi eksternal $34,3 \% .^{5}$

Radikalisme merupakan faham, wacana dan aktivisme yang berupaya mengubah sistem politik, ekonomi, sosial dan budaya yang ada secara radikal. Radikalisme memiliki dua dimensi terpenting; Pertama, kekerasan. Dalam pengertian menerima kekerasan sebagai cara yang sah untuk mengubah sistem tersebut; Kedua, usaha aktif melakukan perubahan di dalam masyarakat secara radikal, yang tidak selalu menggunakan kekerasan. ${ }^{6}$ Munculnya radikalisme berbasis agama saat ini menjadi keprihatinan bersama masyarakat Indonesia. Agama yang seharusnya menjadi panduan hidup yang ramah dan toleran justru menjadi penyebab timbulnya kekerasan, teror dan anti pancasila. Itu artinya, ada hal yang salah dalam konteks pemahaman dan implementasi ajaran agama yang sangat fundamental. ${ }^{7}$

Berdasarkan data-data tersebut menunjukkan bahwa radikalisme menyebabkan masyarakat menjadi khawatir akan penyebaran ideologi dan paham radikal di Indonesia. Di Kabupaten Sumbawa Barat Provinsi Nusa Tenggara Barat (NTB) potensi dan

\footnotetext{
${ }^{3}$ Wahid Foundation, "A Measure of The Extent of Socio-Religious Intolerance and Radicalism within Muslim Society in Indonesia" dalam National Survey Report, March-April, (2016).

${ }^{4}$ Lola Loveita, Radikalisme Agama di Indonesia: Urgensi Negara Hadir dan Kebijakan Publik yang Efektif. Background Paper 01 (Jakarta: INFID, 2017).

${ }^{5}$ Rangga Eka Saputra, Api dalam Sekam: Keberagamaan Generasi Z (Convey Report) (Jakarta: Pusat Pengkajian Islam dan Masyarakat (PPIM) UIN Syarif Hidayatullah, 2018).

6 Noorhaidi Hasan, "Memahami Radikalisme Islam" dalam Paper Workshop Membangun Kesadaran dan Strategi dalam Menghadapi Gerakan Radikalisasi Agama, Depok, 19 Desember (2011).

${ }^{7}$ Jaja Zarkasyi \& Thobib Al-Asyhar, Radikalisme Agama dan Tantangan Kebangsaan (Jakarta: Direktorat Jenderal Bimas Islam Kemenag RI, 2014).
} 
ancaman penyebaran paham radikal semakin menguat dan subur menyebar. ${ }^{8}$ Hal ini disebabkan oleh adanya beberapa organisasi kemasyarakatan yang memiliki doktrin keagamaan khilafah yang bertentangan dengan Pancasila, seperti Khilafatul Muslimin, Hizbut Tahrir Indonesia (HTI) Sumbawa Barat, serta Jamaah Salafi. Meski di sisi lain ada organisasi kemasyarakatan seperti Nahdatul Ulama (NU), Muhammadiyah, Nahdatul Wathan (NW) dan Majelis Ulama Indonesia (MUI) Sumbawa Barat yang cenderung memiliki pemahaman keagamaan yang moderat. Oleh karena itu, penelitian ini bertujuan untuk mengetahui faktor-faktor apa saja yang bisa menjadi pemicu lahirnya radikalisme agama serta strategi apa yang bisa dilakukan untuk menangkal masuknya paham radikal di Kabupaten Sumbawa Barat.

\section{Tinjauan Pustaka}

Beberapa penelitian sebelumnya mengenai radikalisme terutama terkait dengan bagaimana upaya maupun langkah mencegah masuknya paham radikal, misalnya dilakukan oleh Nur Kafid. Dalam studinya yang mengambil kasus UIN Maulana Malik Ibrahim, Malang, menyebutkan bahwa ma'had (asrama) bisa dijadikan salah satu model dalam membentengi masuknya pengaruh paham keagamaan radikal bagi mahasiswa baru. Di samping itu, kebijakan dalam bentuk kewajiban bagi mahasiswa baru untuk mengalami proses 'penggemblengan' di ma'had (asrama) agar tidak terpapar radikalisme, memberikan penanaman wawasan keagamaan yang toleran dan moderat, serta praktik pluralisme bagi sivitas akademika juga menjadi kebijakan yang efektif dalam mencegah masuknya paham radikal jika dilakukan secara integrative. ${ }^{9}$ Studi Mohammad Syairozi Dimyathi Ilyas dan Fatihunnada juga menemukan hal serupa. Di mana lembaga pendidikan sangat berperan penting dalam rangka menangkal paham radikal. Dengan mengambil kasus pondok pesantren Darus Sunnah yang didirikan oleh Ali Mustafa Yaqub, studi ini menemukan bahwa upaya dalam rangka mencegah pemikiran radikal dapat dilakukan melalui sistem pendidikan yang fokus dalam empat

8 Kobarksb.com, "Sumbawa Barat Rawan Disusupi Paham Radikal" dalam https://kobarksb.com/bumi-paleba/sumbawa-barat-rawan-disusupi-paham-radikal/ diakses 16 Juni 2018. Lihat juga; Radarlombok.co.id, "NTB Hilangkan Stigma Daerah Radikalisme" dalam https://radarlombok.co.id/ntb-hilangkan-stigma-daerah-radikalisme.html diakses 20 Desember 2019.

9 Nur Kafid, "Ma'had sebagai Role Model De-radikalisasi" dalam DINIKA Journal of Islamic Studies, Vol. 13, No. 2 (2015), h. 21-33. 
aspek, yakni kurikulum, metode pembelajaran, penanaman karakter, serta pendidik. ${ }^{10}$ Empat aspek inilah yang kemudian berperan besar dalam menanamkan nilai-nilai moderat melalui para alumninya.

Sementara riset Nitra Galih Imansari menemukan bahwa strategi kontra radikalisasi dan deradikalisasi merupakan upaya yang dilakukan oleh Nahdlatul Ulama di Jawa Timur dalam rangka menangkal paham radikal. Kontra radikalisasi adalah melakukan upaya penanaman nilai-nilai ke-Indonesia-an serta nilai-nilai non kekerasan. Sedangkan deradikalisasi merujuk pada upaya untuk meluruskan pemahaman keagamaan yang sempit menjadi luas dan komprehensif. ${ }^{11}$ Adapun hasil studi Zaimah menunjukkan bahwa beberapa langkah yang dilakukan oleh SDIT Assalamah dalam menangkal masuknya paham radikal di antaranya melakukan seleksi terhadap bukubuku pelajaran, mengembangkan modul pribadi, menyiapkan buku panduan Pendidikan Agama Islam bagi semua guru yang sesuai dengan visi misi sekolah dan kurikulum pendidikan nasional, serta konsisten melaksanakan kegiatan yang memperkuat nasionalisme. ${ }^{12}$ Sedangkan penelitian Ali Muhtarom fokus pada aktor individu di mana ulama dan kyai menjadi pihak yang bisa menjalankan peran kultural dalam menangkal radikalisme di Kabupaten Batang di antaranya dengan memberikan pemahaman keagamaan yang sesuai dengan ajaran Islam yang rahmatan lil 'alamin. ${ }^{13}$

Secara umum, penelitian terdahulu membahas kebijakan, peran dan upaya yang dilakukan oleh berbagai institusi pendidikan, organisasi keagamaan serta peran tokoh agama dalam mencegah masuknya paham radikal. Hanya saja, belum ada yang menggunakan analisis SWOT untuk mengidentifikasi maupun merumuskan langkahlangkah antisipatif dalam mencegah masuknya paham radikal, terutama bagi institusi pemerintahan di daerah. Atas dasar itu, studi ini menggunakan metode kuantitatif untuk menganalisis apa saja strategi yang bisa dilakukan oleh Pemerintah Kabupaten

\footnotetext{
${ }^{10}$ Mohammad Syairozi Dimyathi Ilyas \& Fatihunnada, "The Role of Religious Institutions in Preventing Radical Leftism" dalam Proceedings of the 2nd International Conference on Islam, Science and Technology -ICONIST (2019).

${ }^{11}$ Nitra Galih Imansari, "Peran Ulama Nahdlatul Ulama dalam Menangkal Radikalisme di Provinsi Jawa Timur". Tesis. (Surabaya: Pascasarjana UIN Sunan Ampel, 2019), h. 139-140.

${ }_{12}$ Zaimah, "Strategi Menangkal Radikalisme melalui Pembelajaran PAI di Sekolah Dasar Islam Terpadu (SDIT) Assalamah, Bandarjo, Kec. Ungaran Barat,Kab. Semarang". Tesis. (Semarang: Pascasarjana UIN Walisongo, 2019), ha. 107-116.

${ }_{13}$ Ali Muhtarom, "Peran Ulama dalam Menangkal Radikalisme Agama di Kabupaten Batang Jawa Tengah" dalam RISTEK: Jurnal Riset, Inovasi dan Teknologi Kabupaten Batang, Vol. 1, No. 1 (2016), h. 45-65.
} 
Sumbawa Barat dalam rangka mengantisipasi masuk dan berkembangnya paham radikal di Sumbawa Barat setelah mengidentifikasi faktor-faktor yang bisa memicu kemunculan paham radikal dengan menggunakan metode kualitatif. Studi ini menjadi penting untuk melengkapi studi-studi terdahulu yang telah mengidentifikasi apa saja langkah maupun strategi yang telah dilakukan oleh institusi pendidikan, institusi keagamaan, serta peran tokoh agama dalam menangkal masuknya paham radikal.

\section{Memahami Radikalisme}

Secara teoritik, radikalisme merujuk pada sebuah kepercayaan terhadap ide atau prinsip radikal untuk mewujudkan perubahan ekstrem terhadap institusi politik dan sosial. Dalam pengertian politik, gagasan ini muncul dari Charles James Fox (17491806), seorang negarawan Inggris, yang menginginkan suatu reformasi radikal untuk membela kebebasan dan penghapusan perdagangan budak. Sejak saat itu, ide tersebut kemudian meluas menjadi milik dunia. Kemunculan radikalisme di Indonesia selain disebabkan dimensi global berupa ketidakadilan, faktor domestik seperti kemiskinan serta lemahnya penegakan hukum juga menjadi salah satu faktor dominan. ${ }^{14}$

Sejalan dengan pemikiran di atas, radikalisme merupakan pemikiran, sikap, dan tindakan keagamaan yang cenderung mengedepankan teks-teks secara skriptual dalam memahami agama. Sikap radikalisme keagamaan ini muncul dilatarbelakangi oleh dua faktor. Pertama, faktor internal. Di antara sistem pendidikan dan pola pemahaman agama yang bersifat 'amali yang akan menjadikan agama sebagai sebuah sistem dogma yang absolut dan sebuah kebenaran yang mutlak. Kedua, faktor eksternal. Baik faktor politis karena adanya dominasi, sosiologis disebabkan sikap peminggiran terhadap umat Islam, kultural maupun keagamaan. ${ }^{15}$

Pada dasarnya, radikal ditandai dengan empat hal, yaitu; Pertama, sikap tidak toleran yang tidak mau menghargai pendapat dan keyakinan orang lain. Kedua, sikap tidak toleran yang selalu merasa benar sendiri serta menganggap orang lain salah. Ketiga, sikap eksklusif yang membedakan diri dari kebiasaan masyarakat kebanyakan. Empat, sikap revolusioner yang cenderung menggunakan kekerasan untuk mencapai

\footnotetext{
${ }^{14}$ Ahmad Syafii Maarif, "Radikalisme, Ketidakadilan, dan Rapuhnya Ketahanan Bangsa" dalam Jurnal Maarif, Vol. 5, No. 2 (2010), h. 147-158. 2007).
} 
tujuan. ${ }^{16}$ Apapun bentuknya, baik radikalisme, fundamentalisme, maupun terorisme dari gerakan keagamaan hanya akan membuat agama Islam jauh dari watak aslinya sebagai agama rahmatan lil 'alamin serta membuat agama kehilangan tujuannya yang hakiki. Syariat Islam dengan berbagai perangkatnya diturunkan kepada manusia sebagai fondasi kehidupan (maqashid as-syariah) melindungi seluruh dimensi kemanusiaan serta memudahkan manusia dalam menjalani kehidupannya dengan cinta damai, jauh dari sikap fundamentalisme, radikalisme maupun terorisme.

Dengan demikian, radikalisme merupakan paham (isme), tindakan yang melekat pada seseorang atau kelompok yang menginginkan perubahan, baik sosial, politik dengan menggunakan kekerasan, berpikir asasi dan bertindak ekstrim. ${ }^{17}$ Sementara menurut Baradat, radikalisme merujuk pada seseorang atau kelompok yang menginginkan perubahan fundamental datang secara cepat. Untuk itu, cara ekstrim pun akan dilakukan untuk mengatasi kondisi masyarakat yang ada. Terdapat beberapa faktor yang melahirkan gerakan radikal tumbuh dan berkembang, seperti faktor pemahaman keagamaan yang sempit, faktor ketidakadilan secara politik dan ekonomi. Dalam praktiknya, seringkali kelompok-kelompok radikal menggunakan cara-cara yang keras terhadap kelompok lain yang berseberangan pendapat dengan keyakinan mereka. ${ }^{18}$

Adapun Kartodirdjo menjelaskan radikalisme sebagai "gerakan sosial yang menolak secara menyeluruh tertib sosial yang sedang berlangsung dan ditandai oleh kejengkelan moral yang kuat untuk menentang dan bermusuhan dengan kaum yang memiliki hak-hak istimewa dan yang berkuasa". ${ }^{19}$ Dengan kata lain, radikalisme merupakan gejala umum yang bisa terjadi dalam suatu masyarakat dengan motif beragam, baik sosial, politik, budaya maupun agama, yang ditandai oleh tindakantindakan keras, ekstrim, dan anarkis sebagai wujud penolakan terhadap gejala yang dihadapi. $^{20}$

\footnotetext{
${ }^{16}$ A. Maftuh Abegebriel \& A. Yani Abeveiro, Negara Tuhan: The Thematic Encyclopaedia (Yogyakarta: SR-Ins Publishing, 2004).

${ }_{17}$ Tim Penyusun Pusat Pengembangan Bahasa, Kamus Besar Bahasa Indonesia (Jakarta: Depdikbud \& Balai Pustaka, 1998).

${ }^{18}$ Leon P. Baradat, Political Ideologies Their Origins and Impact (New Jersey: Prentice-Hall, Inc, 1994).

${ }^{19}$ Sartono Kartodirjo, Ratu Adil (Jakarta: Sinar Harapan, 1985). h. $842-853$.

${ }^{20}$ Mohammad Kosim, "Pesantren dan Wacana Radikalisme" dalam Karsa, Vol. 9, No. 1 (2006),
} 
Lazuardi Birru dan LSI yang melakukan penelitian tahun 2010 mendefinisikan radikalisme sebagai tindakan dan/atau sikap atas paham yang tidak sejalan dengan prinsip-prinsip kehidupan berbangsa yang menjunjung tinggi sikap toleran dan terbuka terhadap sesama warga yang majemuk dari latar belakang primordialnya dan dijamin keberadaannya oleh konsitusi. Radikalisme adalah aksi seseorang atau sekelompok orang yang bertentangan dengan prinsip-prinsip kemanusiaan. ${ }^{21}$ Merujuk beberapa definisi konseptual di atas, dalam kajian ini definisi operasional yang penulis gunakan merujuk pada sikap maupun tindakan yang menggunakan identitas agama yang bertentangan dengan nilai-nilai dan prinsip dasar dalam kehidupan berbangsa dan bernegara.

\section{Analisis SWOT}

Analisis SWOT dipilih dalam merumuskan strategi dan aksi yang dapat dilakukan dalam rangka menangkal masuknya paham radikal di Kabupaten Sumbawa Barat. Analisis ini dipilih karena merupakan analisis data kuantitatif yang sederhana, fleksibel, integratif dan kolaboratif dalam merumuskan suatu strategi. Menurut Rangkuti, analisis SWOT adalah identifikasi berbagai faktor secara sistematis untuk merumuskan strategi kebijakan. ${ }^{22}$ Analisis ini didasarkan pada logika yang terdiri dari kekuatan (strengths), kelemahan (weaknesses), peluang (opportunities) dan ancaman (threats). Analisis SWOT setidaknya menghasilkan strategi sebagai berikut: ${ }^{22}$

\section{Strategi SO (Strengths Opportunities )}

Strategi yang dilakukan dengan cara memanfaatkan kekuatan yang ada melalui kesempatan yang dimiliki.

2. Strategi ST (Strengths Threats)

Strategi yang digunakan dengan cara memanfaatkan kekuatan yang dimiliki untuk mengatasi ancaman dari luar.

\section{Strategi WO (Weaknesses Opportunities)}

Strategi ini diterapkan berdasarkan pemanfaatan peluang yang ada untuk meminimalkan kelemahan yang dimiliki.

21 Dhyah Madya Ruth (Ed.), Memutus Mata Rantai Radikalisme dan Terorisme (Jakarta: Lazuardi Birru, 2010).

${ }^{22}$ Freddy Rangkuti, Analisis SWOT: Teknik Membedah Kasus Bisnis (Jakarta: Gramedia Pustaka Utama, 2006). 


\section{Strategi WT (Weaknesses Threats)}

Strategi yang digunakan dengan cara meminimalkan kelemahan yang ada serta menghindari ancaman dari luar.

Tabel 1:

Matrik Analisis SWOT

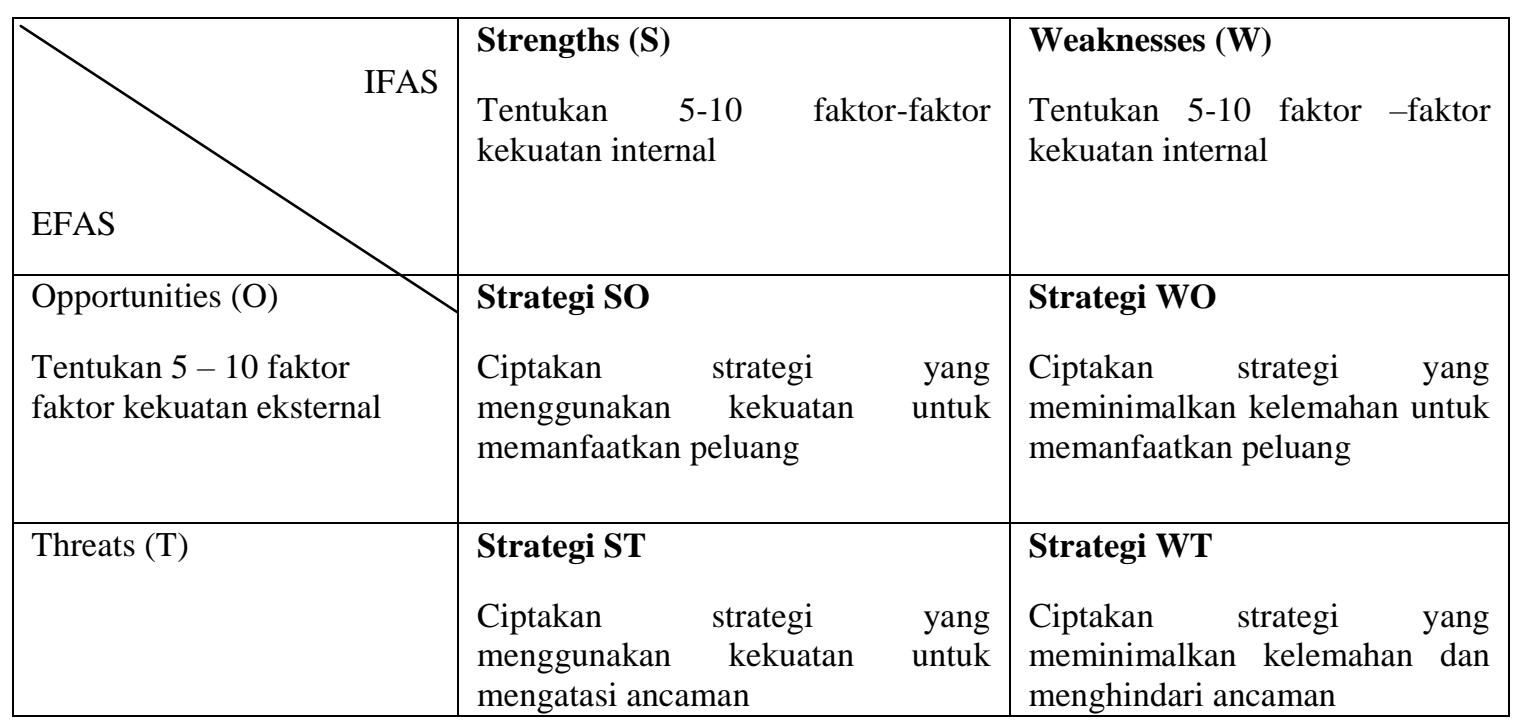

\section{Metode Penelitian}

Penelitian ini menggunakan metode penelitian mixed method yaitu metode pendekatan kuantitatif dan kualitatif. Menurut Sugiyono, metode penelitian kualitatif adalah metode dalam meneliti status kelompok individu, suatu objek dengan tujuan membuat deskripsi, gambaran atau lukisan secara sistematis, faktual dan akurat mengenai fakta-fakta atau fenomena yang diselidiki. Sedangkan metode penelitian kuantitatif, merupakan data yang diperoleh dari sampel penelitian yang dianalisis sesuai dengan metode statistik yang digunakan. ${ }^{23}$

Penelitian ini dilakukan di Kabupaten Sumbawa Barat, Provinsi Nusa Tenggara Barat. Lokasi penelitian terfokus di dua kecamatan di Sumbawa Barat; Kecamatan Taliwang dan Kecamatan Maluk. Pemilihan lokasi sampel dilakukan secara purposive sampling karena kedua kecamatan tersebut merupakan basis utama lembaga keagamaan dan organisasi kemasyarakatan di Kabupaten Sumbawa Barat. Pengumpulan data dalam penelitian ini dilakukan dengan teknik survei melalui wawancara menggunakan

\footnotetext{
${ }^{23}$ Sugiyono, Memahami Penelitian Kualitatif (Bandung: Alfabeta, 2012).
} 
kuesioner penelitian. Wawancara dilakukan dengan 30 responden yang terdiri atas pimpinan pesantren di wilayah Sumbawa Barat, MUI Kabupaten Sumbawa Barat, pimpinan NU, Kementerian Agama Kabupaten Sumbawa Barat, Kepolisian Resor (Polres) Sumbawa Barat, dan Komando Distrik Militer (Kodim) Sumbawa Barat. Untuk mengetahui faktor-faktor pemicu lahirnya radikalisme agama di Kabupaten Sumbawa Barat dianalisis menggunakan metode interactive model. Menurut Miles dan Huberman, analisis data dalam sebuah penelitian kualitatif berlangsung selama dan setelah pengumpulan data. ${ }^{24}$ Pengolahan data kualitatif dilakukan dengan cara mereduksi data (data reduction) yang terkumpul, penyajian data (data display), dan penarikan kesimpulan dan verifikasi data (conclusion drawing and verification). ${ }^{25}$

Sedangkan untuk mengetahui strategi menangkal radikalisme agama di Sumbawa Barat, digunakan analisis SWOT yang merupakan pendekatan penelitian kuantitatif. Dalam analisis SWOT akan menghasilkan beberapa alternatif strategi dan aksi yang dapat dilakukan untuk menangkal radikalisme agama. Strategi yang dihasilkan adalah sebagai berikut; Strategi SO (Strengths Opportunities), strategi ST (Strengths Threats), strategi WO (Weaknesses Opportunities), dan strategi WT (Weaknesses Threats). ${ }^{26}$ Adapun tahapan analisis SWOT yaitu sebagai berikut:

Pertama, pada kolom 1 dilakukan penyusunan dan identifikasi semua faktor yang dimiliki oleh Pemerintah Kabupaten Sumbawa Barat dalam menangkal radikalisme agama menjadi faktor internal (kekuatan dan kelemahan) dan faktor eksternal (peluang dan ancaman). Kedua, pemberian bobot masing-masing faktor pada kolom 2, mulai 1,0 (sangat penting) sampai dengan 0,0 (tidak penting). Ketiga, pada kolom 3 dilakukan perhitungan faktor-faktor berdasarkan pengaruhnya. Nilai rating mulai 1 (kurang berpengaruh) sampai dengan 5 (sangat berpengaruh). Keempat, kolom 4 dilakukan perhitungan dengan cara mengalikan bobot pada kolom 2 dengan rating pada kolom 3. Kelima, penjumlahan total skor pembobotan untuk masing-masing faktor internal (kekuatan dan kelemahan) dan eksternal (peluang dan ancaman).

\footnotetext{
${ }^{24}$ Matthew B. Miles \& A Michael Huberman, Analisis Data Kualitatif (Jakarta: UI Press, 1992).

${ }^{25}$ Agus Salim, Teori dan Paradigma Penelitian Sosial: Buku Sumber untuk Penelitian Kualitatif (Yogyakarta: Tiara Wacana, 2006).

${ }^{26}$ Freddy Rangkuti, Loc.Cit.
} 


\section{Sekilas Kabupaten Sumbawa Barat}

Kabupaten Sumbawa Barat merupakan salah satu daerah dari sembilan kabupaten/kota yang berada pada di wilayah Provinsi Nusa Tenggara Barat. Secara geografis terletak antara $08^{\circ} 29^{\prime}$ dan $9^{\circ} 07^{\prime}$ LS dan antara $116^{\circ} 42^{\prime}-117^{\circ} 05^{\prime}$ BT. Posisi ini tergolong cukup strategis karena merupakan 'Pintu Gerbang' dari Pulau Lombok menuju Pulau Sumbawa. Sedangkan secara administrasi, memiliki batas-batas wilayah sebagai berikut; sebelah Utara berbatasan dengan Kecamatan Alas Barat dan Alas Kabupaten Sumbawa, sebelah Timur berbatasan dengan Kecamatan Batu Lanteh dan Lunyuk Kabupaten Sumbawa, sebelah Selatan berbatasan dengan Samudera Indonesia; dan sebelah Barat berbatasan dengan Selat Alas.

Luas wilayah Kabupaten Sumbawa Barat sekitar $1.849 .02 \mathrm{~km}^{2}$ yang dibagi menjadi 8 kecamatan dan 65 desa. Kecamatan yang memiliki jumlah desa terbanyak adalah Kecamatan Taliwang (15 desa), sedangkan yang jumlah desanya paling sedikit adalah Kecamatan Jereweh hanya memiliki 4 desa. Berdasarkan data Kantor Kementerian Agama Sumbawa Barat, jumlah pemeluk agama Kabupaten Sumbawa Barat tahun 2017 yang terdiri dari pemeluk Agama Islam mencapai 131.923 jiwa, kemudian pemeluk Agama Kristen/Katolik sebanyak 443 jiwa dan Agama Hindu sebanyak 1.663 jiwa. Sementara pemeluk agama Budha dan Konghucu belum ada data yang disajikan oleh Badan Pusat Statistik Kabupaten Sumbawa Barat hingga tahun 2017.

Di Kecamatan Taliwang sebagai salah satu lokasi penelitian, kehidupan sosial masyarakat relatif kondusif. Hal ini menjadi perhatian pemerintah daerah, sebab kota Taliwang merupakan wajah Kabupaten Sumbawa Barat. Di samping itu, terdapat 3 pondok pesantren yang berdiri di Kecamatan Taliwang sebagai tempat belajar ilmu agama dengan santri sekitar 820 orang hingga tahun 2017. Dari sisi tenaga pengajar atau pengasuh, sedikitnya ada sekitar 158 pengasuh yang berkontribusi terhadap penyebaran paham keagamaan kepada para santri. Di Kabupaten Sumbawa Barat pada umumnya paham keagamaan yang dianut adalah Sunni. Termasuk pesantren yang ada di Sumbawa Barat juga memegang teguh prinsip-prinsip ke-Sunnia-an tersebut. Meski demikian, kelompok keagamaan yang mengusung ide khilafah dan pengusung ide syariat Islam seperti Khilafatul Muslimin, Hizbut Tahrir Indonesia (HTI) Sumbawa Barat (DPD HTI 
KSB), Lembaga Dakwah Islam Indonesia (LDII) Cabang Sumbawa Barat serta Jamaah Salafi juga berpusat di Kecamatan Taliwang.

Sementara di Kecamatan Maluk, agama menjadi faktor perekat hubungan sosial antar sesama warga meski banyak pendatang yang mencari peruntungan seiring dengan keberadaan perusahaan PT. Newmont Nusa Tenggara yang sekarang telah berubah menjadi PT. AMNT. Kehidupan sosial keagamaan di Maluk relatif toleran. Meski demikian, potensi terjadinya gesekan sosial berbasis etnis dengan pemahamaman keagamaan tertentu juga besar. Sebagai konsekuensi dari multikulturalnya penduduk Kecamatan Maluk menyebabkan kemunculan organisasi sosial kemasyarakatan berbasis etnis atau suku juga tidak bisa dihindari seperti Ikatan Keluarga Sulawesi Selatan (IKSS), Ikatan Keluarga Bima Dompu, Ikatan Keluarga Jawa (Margo Utomo), Ikatan Keluarga Lombok, Ikatan Keluarga Sasak serta berbagai organisasi sosial kemasyarakatan lainnya turut menjadikan wajah Kecamatan Maluk menjadi heterogen.

\section{Faktor-faktor yang Berpotensi Memicu Lahirnya Radikalisme Agama di Kabupaten Sumbawa Barat}

Dari semua narasumber yang diwawancarai, semua memiliki kesamaan pandangan bahwa radikalisme agama di Sumbawa Barat belum mewujud dalam tindakan nyata di lapangan. Hanya saja, semua bersepakat bahwa potensi ke arah tindakan radikal sudah mulai muncul, setidaknya radikalisme dalam pemahaman diskursif. Oleh sebab itu, pemerintah berkewajiban untuk menyiapkan strategi antisipatif agar tindakan radikal tidak mengganggu kehidupan harmonis masyarakat Sumbawa Barat. Menurut ustadz US, dari Kementerian Agama Sumbawa Barat;

Radikalisme merupakan paham yang memaksakan kehendak, baik secara lisan maupun secara tindakan. Bisa ada pada tingkat yang mengkhawatirkan dan ada pada tingkat yang belum mengkhawatirkan, dan tentunya bertentangan dengan aturan-aturan yang diatur dalam negara kita. Saat ini sudah ada beberapa orang di Kecamatan Seteluk serta kelompok keagamaan yang terindikasi berpaham radikal berdasarkan temuan dari Kemenag. ${ }^{27}$

\footnotetext{
${ }^{27}$ Ustadz US, Kementerian Agama Kabupaten Sumbawa Barat, wawancara, 6 Juni 2018.
} 
Berdasarkan temuan di lapangan, setidaknya terdapat beberapa penyebab yang bisa diidentifikasi dan berpotensi mendorong kemunculan radikalisme agama di Kabupaten Sumbawa Barat yaitu:

\section{Ketidakpuasan Terhadap Kebijakan Pemerintah}

Dari berbagai pendapat responden kunci, sebagian besar menyatakan bahwa salah satu faktor yang bisa menjadi pemicu lahirnya radikalisme agama adalah ketidakpuasan terhadap kebijakan pemerintah. Dalam wawancara yang dilakukan terhadap responden kunci seperti pimpinan pesantren di wilayah Sumbawa Barat, MUI Kabupaten Sumbawa Barat, Pengurus Cabang NU, Kementerian Agama Kabupaten Sumbawa Barat, Kepolisian Resor (Polres) Sumbawa Barat, dan Komando Distrik Militer (Kodim) Sumbawa Barat disebutkan bahwa kebijakan yang kurang bisa mengakomodasi semua kelompok masyarakat serta adanya kesenjangan sosial di tengah masyarakat dapat berkontribusi mendorong tindakan radikal.

Hal ini misalnya diungkapkan ustadz MI dari Majelis Ulama Kabupaten Sumbawa Barat yang menyebut radikalisme bisa muncul salah satunya dipicu oleh ketidakpuasan terhadap kebijakan pemerintah. Sebagaimana diungkapkan ustadz MI;

Secara potensi, ada kelompok radikal di Kabupaten Sumbawa Barat. Radikalisme itu muncul karena adanya ketidakpuasan terhadap kebijakan pemerintah. Potensinya ada. Ada kelompok yang memiliki pemikiran radikal (mereka punya idealisme yang sama untuk menegakkan khilafah), tetapi belum menunjukkan diri dalam organisasi formal. Gerakan-gerakan seperti itu kan tidak pernah mau memformalkan diri dalam satu organisasi. Walaupun tidak terorganisir, tapi biasanya komunikasi mereka juga intens apalagi dengan dukungan teknologi seperti saat ini, mereka sangat aktif. MUI juga meminta agar kelompok-kelompok tersebut juga dipantau di tiap-tiap kecamatan. ${ }^{28}$

Kebijakan pemerintah yang dimaksud misalnya kebijakan di level nasional yang bisa memicu aksi ketidakpuasan di daerah oleh sekelompok masyarakat. Kebijakan pembubaran Hizbut Tahrir Indonesia (HTI) menurut simpatisan kelompok ini dianggap sebagai bentuk penolakan pemerintah terhadap ideologi khilafah yang merupakan salah satu ajaran Islam. Sementara di Sumbawa Barat, kelompok simpatisan ideologi khilafah

\footnotetext{
${ }^{28}$ Ustadz MI, Majelis Ulama Indonesia Kabupaten Sumbawa Barat, wawancara, 7 Juni 2018.
} 
meski relatif belum terlalu besar, namun secara kelembagaan mereka solid melakukan dakwah dengan pendekatan personal. Kebijakan yang dianggap tidak pro terhadap ajaran Islam ini secara teoritik semakin memperkokoh cita-cita kelompok ini untuk senantiasa memerangi sistem yang dianggap sekuler di Indonesia. Meskipun di Sumbawa Barat kelompok ini belum menunjukkan indikasi untuk melakukan aksi radikal dalam tindakan, hanya saja secara pemikiran kelompok ini semakin intensif dalam berdakwah.

\section{Lemahnya Pengawasan Pemerintah Terhadap Sekolah Yang Terindikasi Gerakan Radikal}

Mengonfirmasi temuan beberapa survei sebelumnya yang telah dilakukan lembaga seperti Wahid Institute, Pusat Pengkajian Islam Masyarakat (PPIM), dan Setara Institute, yang menyebutkan bahwa indikasi terjadinya penyebaran ajaran intoleransi dan paham radikal terjadi di lembaga pendidikan di Indonesia, studi ini juga menemukan hal serupa. ${ }^{29}$ Di Sumbawa Barat, ada sekolah yang anti terhadap upacara bendera. Padahal, upacara bendera merupakan bagian dari penghormatan terhadap simbol negara. Sejak tahun 2017 lalu, Bupati Sumbawa Barat telah mengakui dan mewaspadai salah satu sekolah yang tidak mau menghormati bendera merah putih pada acara rutin yang dilaksanakan. ${ }^{30}$ Begitu pula dengan menyanyikan lagu Indonesia Raya. Selain itu, masih ada pemahaman dari sebagian kecil tenaga pengajar yang menganggap penghormatan terhadap bendera merah putih merupakan bentuk dari kesyirikan. Pemahaman seperti ini menjadi masalah karena guru inilah yang mentransfer pengetahuan dan nilai kepada peserta didik. Akibatnya, peserta didik tidak mau memberikan sikap hormat terhadap bendera merah putih serta tidak menyanyikan lagu Indonesia Raya.

Dari beberapa kajian sebelumnya ditemukan fakta bahwa penolakan terhadap simbol-simbol negara menjadi indikasi awal seorang siswa sudah dimasuki paham radikal. Sebut saja, tidak mau menghormat kepada bendera merah putih, menolak

${ }^{29}$ Agus Mutohar, "Radikalisme di Sekolah Swasta Islam: Tiga Tipe Sekolah yang Rentan" dalam http://theconversation.com/radikalisme-di-sekolah-swastaislam-tiga-tipe-sekolah-yangrentan 96722 diakses 25 Desember 2019.

30 Suarantb.com, "Bupati KSB Ungkap Gelagat Intoleransi di KSB” dalam https://www.suarantb.com/pilihan.editor/2017/239577/Bupati.KSB.Ungkap.Gelagat.Intoleransi.di.KSB/ diakses 20 April 2020. 
sistem negara yang ada, menginginkan ada sistem negara yang lain, membenci orang lain yang tidak sependapat dengan keyakinannya, serta membenci aparat negara tanpa alasan yang masuk akal. Studi yang dilakukan Munzir di salah satu pesantren di Kota Batu, Jawa Timur, misalnya, menunjukkan bahwa tidak melaksanakan upacara bendera maupun tidak memasang foto presiden dan wakil presiden di ruangan merupakan indikasi awal dari ciri-ciri kelompok berpaham radikal. ${ }^{31}$ Fakta yang mirip dengan temuan Munzir juga diungkapkan oleh ustadz AAF:

Saya lihat di lembaga ini (sekolah di bawah naungan Yayasan As-Salam), upacaranya tidak ada, pelajaran Pancasilanya juga tidak ada. Seharusnya pemerintah turun tangan ketika ada yang seperti itu terutama dinas terkait ketika memproses ijin, kurikulumnya harus jelas, kemudian disupervisi rutin, benar apa tidak dalam kegiatan belajar mengajar sesuai dengan kurikulum ketika mengajukan ijin itu. Karena, mohon maaf, saya lihat sekolah yang tidak ada upacara, yang tidak ada pelajaran PKN atau Pancasila, kecenderungan ke arah radikal itu tinggi. Dalam hal seperti ini, kita harus punya sikap tegas. Semua elemen termasuk MUI juga harus tegas agar peluang berkembangnya pahampaham seperti ini tidak ada. Apabila model pendidikan yang seperti ini terus dikembangkan, maka besar kemungkinan akan menjadi radikal. Kalau sekolah tersebut tidak mau, sekolahnya harus dibubarkan. ${ }^{32}$

Oleh karena itu, pengawasan pemerintah terhadap lembaga pendidikan di Sumbawa Barat harus ditingkatkan. Pemerintah daerah bertanggung jawab menjamin keberlangsungan pendidikan yang dilakukan oleh negara maupun oleh pihak masyarakat melalui yayasan pendidikan di Sumbawa Barat pada satu sisi. Namun pada saat yang sama, peran pemerintah untuk menjaga ideologi dan dasar negara Pancasila, Undang-Undang Dasar Tahun 1945, Negara Kesatuan Republik Indonesia dan Bhineka Tunggal Ika harus tetap diutamakan. Untuk itu, ketika di sekolah ada oknum yang tidak mau menghormati simbol-simbol negara, pemerintah harus cepat tanggap untuk melakukan pembinaan.

${ }^{31}$ Munzir. "Identifikasi Isu Radikalisme di Pesantren Salafi” dalam Kalam, Vol. 7, No. 1, (2019), h. 53.

${ }^{32}$ Ustadz AAF, Sekretaris Pengurus Cabang Nahdlatul Ulama Kabupaten Sumbawa Barat, wawancara, 9 Juni 2018. 
Pemahaman Keagamaan Yang Merasa Paling Benar Dibandingkan Kelompok Lainnya

Di Kabupaten Sumbawa Barat, ada kelompok keagamaan yang ingin menegakkan syariat Islam melalui sebuah sistem ke-khalifahan, diantaranya Khilafatul Muslimin, Hizbut Tahrir Indonesia (HTI) Sumbawa Barat (yang saat ini telah mengganti identitas dakwahnya), serta Jamaah Salafi. Meskipun pada praktiknya kelompok keagamaan tersebut masih melaksanakan ajaran dan pemahaman keagamaannya secara internal. Hanya saja, jika ditelusuri lebih jauh, apa yang diyakini sebagai sistem ke-khalifahan (sistem berbasis keagamaan) tersebut pada dasarnya dipahami sebagai sebuah kebenaran tunggal yang diimpikan dapat menyelesaikan permasalahan ketimpangan sosial ekonomi serta krisis dalam dunia Islam pada khususnya. Implikasi serius pemahaman keagamaan tersebut adalah adanya potensi gesekan sosial dalam masyarakat. Hal ini terjadi sebab kelompok tersebut memiliki tafsir ajaran yang mereka yakini berada pada ekstremitas yang berseberangan dengan prinsip negara modern sebagaimana dianut dan dijalankan di Indonesia. ${ }^{33}$

Dengan adanya pemahaman seperti ini, kelompok di luar kelompoknya bisa jadi akan dianggap sebagai musuh yang bisa diperangi ke depannya. Kondisi seperti ini cenderung memunculkan kelompok umat yang memiliki gairah tinggi dalam menjalankan perintah agama, namun pada saat yang sama, cenderung menganggap kelompok yang berada di luar kelompoknya adalah tidak benar. Dengan kata lain, ada gejala yang menganggap pemahaman keagamaan kelompoknya lebih baik dan benar daripada kelompok keagamaan lain. Akibatnya, potensi kemunculan konflik antar sesama umat beragama menjadi tinggi. Fakta ini perlu menjadi atensi pemerintah daerah dalam rangka memetakan dan melakukan tindakan preventif. Tujuannya jangan sampai terjadi tindakan radikal terhadap kelompok lain yang mempunyai pemahaman keagamaan yang berseberangan dengan kelompok keagamaan yang mengusung sistem politik berbasis keagamaan.

Lebih jauh, pemahaman keagamaan yang eksklusif sangat meyakini bahwa penafsiran keagamaan kelompoknya sendiri yang paling benar. Sementara kebenaran

\footnotetext{
${ }^{33}$ INFID, Urgensi dan Strategi Efektif Pencegahan Ekstrimisme di Indonesia (Jakarta: INFID, 2018).
} 
versi kelompok keagamaan lainnya dianggap salah dan sesat. ${ }^{34}$ Sebab nalar yang dikembangkan oleh sikap dan pandangan ini adalah nalar dan pemahaman keagamaan yang tidak toleran, tidak akomodatif terhadap segala perbedaan, lebih suka mencari titik perbedaan, dan ukuran kebenaran yang digunakan adalah kebenaran mayoritas. Dengan kata lain, pemahaman keagamaan yang lebih menitikberatkan pada aspek teologis, eksklusif dan dogmatik hanya akan menjadikan agama sebagai sumber bencana. Sedangkan pemahaman keagamaan yang teoritik, normatik dan tertutup akan membuat penganutnya mudah menuduh, menghakimi dan berprasangka buruk kepada orang lain yang berbeda. ${ }^{35}$

\section{Analisis SWOT Menangkal Radikalisme Agama di Kabupaten Sumbawa Barat}

Radikalisme merupakan ancaman serius bagi kehidupan berbangsa dan bernegara di Indonesia tidak terkecuali di Provinsi Nusa Tenggara Barat khususnya di Kabupaten Sumbawa Barat. Setelah mengetahui faktor-faktor yang berpotensi mendorong kemunculan radikalisme berbasis agama di Sumbawa Barat, maka kerja sama semua pihak sangat diperlukan. Oleh sebab itu, dalam rangka mencegah radikalisme agama di Kabupaten Sumbawa Barat, penentuan strategi dalam penelitian ini dilakukan dengan meminjam analisis SWOT (Strength, Weakness, Opportunity, Threat). Kondisi yang berasal dari dalam kehidupan masyarakat Sumbawa Barat sendiri yang memiliki sifat positif (kekuatan) dan sifat negatif (kelemahan) dilihat sebagai faktor internal, sementara faktor-faktor yang berasal dari luar Sumbawa Barat sendiri dalam bentuk peluang dan ancaman disebut sebagai faktor eksternal. Berdasarkan temuan dan hasil penelitian diperoleh faktor internal dan faktor eksternal sebagai berikut:

\section{Faktor Internal}

Faktor internal yang berasal dari dalam kehidupan masyarakat Sumbawa Barat sendiri, terdiri atas faktor kekuatan (strength) dan faktor kelemahan (weakness).

34 Idrus Ruslan, Reorientasi Fungsi Lembaga-Lembaga Keagamaan dalam Meningkatkan Perilaku Umat Beragama yang Inklusif: Studi Terhadap MUI, PGI, PHDI dan Walubi Provinsi Lampung (Lampung: Pusat Penelitian dan Penerbitan LP2M IAIN Raden Intan Lampung, 2014).

35 Anis Farikhatin, "Membangun Keberagamaan Inklusif-Dialogis di SMA PIRI I Yogyakarta" dalam Jurnal Maarif, Vol. 8, No. 1 (2013), h. 109-131. 
a. Kekuatan (Strength)

- Adanya dukungan kebijakan pemerintah daerah

- Peran Polri, TNI, masyarakat dan tokoh agama

- Rasa saling menghargai antar agama

- Kondisi sosial keagamaan yang kondusif

b. Kelemahan (Weakness)

- Pemahaman keagamaan tidak sempurna

- Kurangnya pemahaman kebangsaan dan Pancasila

- Masih adanya kelompok masyarakat yang eksklusif dan fanatik

- Kondisi ekonomi masyarakat yang miskin

Faktor Eksternal

Faktor eksternal yang berasal dari luar kehidupan masyarakat Sumbawa Barat sendiri, terdiri terdiri atas faktor peluang (opportunity) dan faktor ancaman (threat).

a. Peluang (Opportunity)

- Regulasi dan kebijakan pemerintah pusat

- Kegiatan peningkatan kebangsaan dan pancasila

- Adanya komunitas cinta damai dan cinta NKRI

b. Ancaman (Threat)

- Adanya kelompok-kelompok Islam aliran keras

- Adanya sarana prasarana penyebaran paham radikalisme

- Masuknya kelompok-kelompok penyebar radikalisme

- Kekecewaan terhadap kebijakan pemerintah

Tabel 2:

Matriks SWOT

\begin{tabular}{|c|c|c|}
\hline & $\begin{array}{l}\text { Strengths: } \\
\text { - } \quad \text { Adanya dukungan kebijakan } \\
\text { pemerintah daerah } \\
\text { - } \quad \text { Peran Polri, TNI, masyarakat } \\
\text { dan tokoh agama } \\
\text { - } \quad \text { Rasa saling menghargai antar } \\
\text { agama } \\
\text { - Kondisi sosial keagamaan } \\
\text { yang kondusif }\end{array}$ & $\begin{array}{l}\text { Weaknesses: } \\
\text { - } \quad \text { Pemahaman keagamaan } \\
\text { tidak sempurna } \\
\text { - } \quad \text { Kurangnya pemahaman } \\
\text { kebangsaan dan Pancasila } \\
\text { - } \quad \text { Masih adanya kelompok } \\
\text { masyarakat yang eksklusif } \\
\text { dan fanatik } \\
\text { - } \begin{array}{l}\text { Kondisi ekonomi } \\
\text { masyarakat yang miskin. }\end{array}\end{array}$ \\
\hline $\begin{array}{l}\text { Opportunities: } \\
\text { - Regulasi dan kebijakan } \\
\text { pemerintah pusat } \\
\text { - Kegiatan peningkatan } \\
\text { kebangsaan dan pancasila } \\
\text { - Adanya komunitas cinta } \\
\text { damai dan cinta NKRI }\end{array}$ & $\begin{array}{l}\text { Strategi (SO): } \\
\text { 1. } \text { Meningkatkan/ } \\
\text { mengoptimalkan } \\
\text { pemerintah, TNI, Peran } \\
\text { Tokoh masyarakat dan agama } \\
\text { dalam melakukan kegiatan } \\
\text { kebangsaan dan cinta } \\
\text { pancasila. } \\
\text { 2. Mengoptimalkan peran serta }\end{array}$ & $\begin{array}{l}\text { Strategi (WO): } \\
\text { 1. Meningkatkan } \\
\text { pemerintah dan tokoh } \\
\text { agama dalam meluruskan } \\
\text { pemahaman tentang agama } \\
\text { dan cinta NKRI. } \\
\text { 2. Melakukan pembinaan } \\
\text { terhadap relompok- } \\
\text { kelompok yang rentan dan }\end{array}$ \\
\hline
\end{tabular}




\begin{tabular}{|c|c|c|}
\hline & 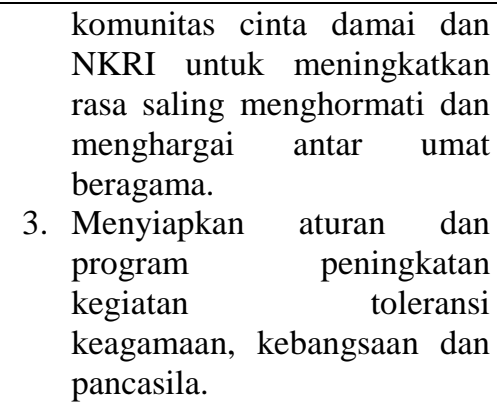 & $\begin{array}{l}\text { radikal. } \\
\text { 3. Peningkatan kegiatan } \\
\text { kebangsaan dan cinta NKRI } \\
\text { terhadap masyarakat. }\end{array}$ \\
\hline 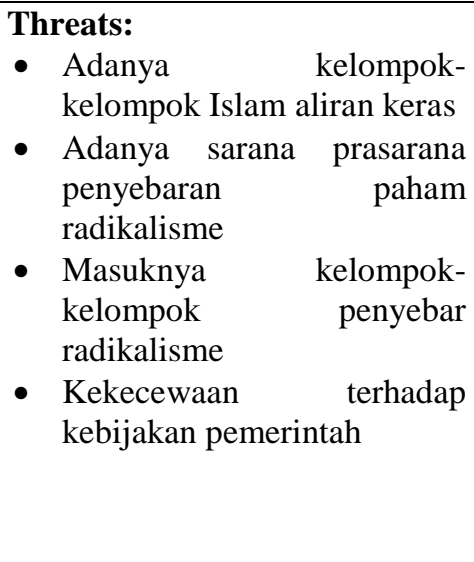 & 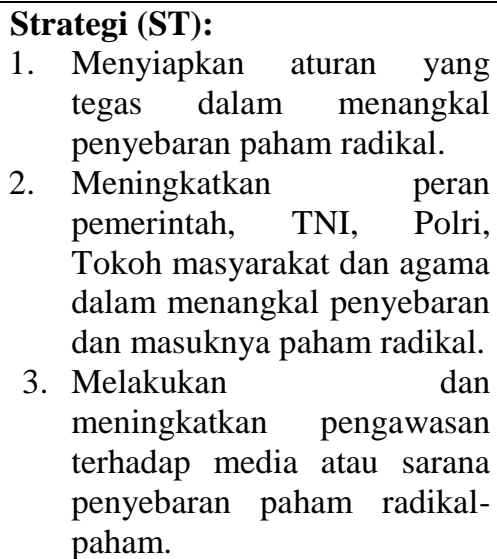 & $\begin{array}{ll}\text { Strategi (WT): } & \\
\text { 1. } & \text { Peningkatan } \\
& \text { kebangsaan dan agama } \\
& \text { terhadap } \\
& \text { kelompok islam aliran } \\
& \text { keras. } \\
\text { 2. } & \text { Mencegah dan mengawasi } \\
& \text { penyebaran paham radikal }\end{array}$ \\
\hline
\end{tabular}

Tabel 3:

Hasil Analisis Internal Factor Analysis Summary (IFAS)

\begin{tabular}{|c|c|c|c|}
\hline Faktor-Faktor Strategi Internal & Bobot & Rating & $\begin{array}{c}\text { Bobot } \\
\text { X Rating }\end{array}$ \\
\hline \multicolumn{4}{|l|}{ Kekuatan } \\
\hline \multirow{5}{*}{ 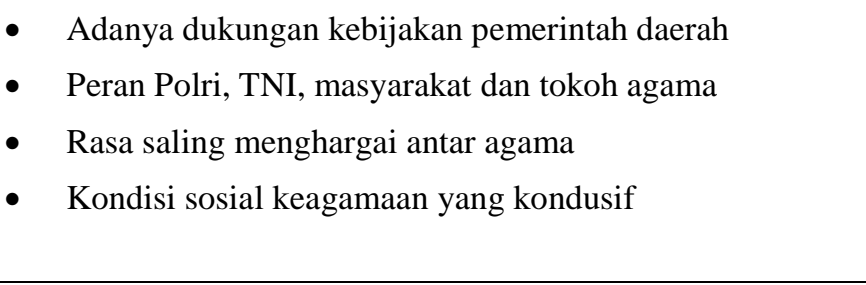 } & 0,16 & 4,00 & 0,62 \\
\hline & 0,14 & 3,50 & 0,48 \\
\hline & 0,16 & 4,00 & 0,62 \\
\hline & 0,17 & 4,25 & 0,70 \\
\hline & & & 2,42 \\
\hline \multicolumn{4}{|l|}{ Kelemahan } \\
\hline \multirow{5}{*}{$\begin{array}{l}\text { - } \text { Pemahaman keagamaan tidak sempurna } \\
\text { - Kurangnya pemahaman kebangsaan dan Pancasila } \\
\text { - } \quad \text { Masih adanya kelompok masyarakat yang eksklusif dan } \\
\text { fanatic } \\
\text { - Kondisi ekonomi masyarakat yang miskin }\end{array}$} & 0,10 & 2,50 & 0,24 \\
\hline & 0,12 & 3,00 & 0,35 \\
\hline & 0,08 & 2,00 & 0,16 \\
\hline & 0,10 & 2,50 & 0,24 \\
\hline & & & 0,99 \\
\hline Sumbu X (Kekuatan - Kelemahan) & & & 1,41 \\
\hline
\end{tabular}

Hasil dari matriks IFAS menunjukkan nilai indeks akumulatif dari kekuatan dan kelemahan serta selisih total nilai bobot skor untuk faktor internal (kekuatan dan 
kelemahan). Hasil dari matriks IFAS diperoleh nilai indeks akumulatif untuk elemen kekuatan sebesar 2.42, sedangkan nilai indeks akumulatif untuk elemen kelemahan diperoleh sebesar 0.99. Hal ini berarti bahwa faktor kekuatan lebih dominan dibandingkan dengan faktor kelemahan, dengan selisih nilai bobot skor adalah 1.41. Hasil tersebut dapat diartikan bahwa dalam menangkal radikalisme agama, Pemerintah Kabupaten Sumbawa Barat memiliki kekuatan yang mampu mengatasi kelemahan yang ada.

Tabel 4:

Hasil Analisis Eksternal Factor Analysis Summary (EFAS)

\begin{tabular}{|c|c|c|c|}
\hline Faktor-Faktor Strategi Eksternal & Bobot & Rating & $\begin{array}{c}\text { Bobot } \\
\text { X } \\
\text { Rating }\end{array}$ \\
\hline \multicolumn{4}{|l|}{ Peluang } \\
\hline \multirow{4}{*}{$\begin{array}{l}\text { - Regulasi dan kebijakan pemerintah pusat } \\
\text { - Kegiatan peningkatan kebangsaan dan pancasila } \\
\text { - Adanya komunitas cinta damai dan cinta NKRI }\end{array}$} & 0,20 & 4,25 & 0,83 \\
\hline & 0,16 & 3,50 & 0,56 \\
\hline & 0,14 & 3,00 & 0,41 \\
\hline & & & 1,81 \\
\hline \multicolumn{4}{|l|}{ Ancaman } \\
\hline \multirow{5}{*}{$\begin{array}{l}\text { - Adanya kelompok-kelompok Islam aliran keras } \\
\text { - Adanya sarana prasarana penyebaran paham radikalisme } \\
\text { - Masuknya kelompok-kelompok penyebar radikalisme } \\
\text { - Kekecewaan terhadap kebijakan pemerintah }\end{array}$} & 0,11 & 2,50 & 0,29 \\
\hline & 0,18 & 4,00 & 0,74 \\
\hline & 0,11 & 2,50 & 0,29 \\
\hline & 0,09 & 2,00 & 0,18 \\
\hline & & & 1,49 \\
\hline TOTAL & & & 0,31 \\
\hline
\end{tabular}

Matriks EFAS menunjukkan nilai indeks akumulatif dari faktor eksternal (peluang dan ancaman) serta selisih total nilai bobot skor untuk faktor eksternal (peluang dan ancaman). Hasil dari matriks EFAS diperoleh nilai indeks akumulatif untuk elemen peluang sebesar 1.81, sedangkan nilai indeks akumulatif untuk elemen ancaman diperoleh sebesar 1.49. Hal ini berarti bahwa faktor peluang lebih dominan dibandingkan dengan faktor ancaman, dengan selisih nilai bobot skor adalah 0.31. Hasil tersebut dapat diartikan bahwa dalam menangkal Pemerintah Kabupaten Sumbawa Barat memiliki peluang yang mampu mengatasi kelemahan yang ada untuk menangkal radikalisme agama. 


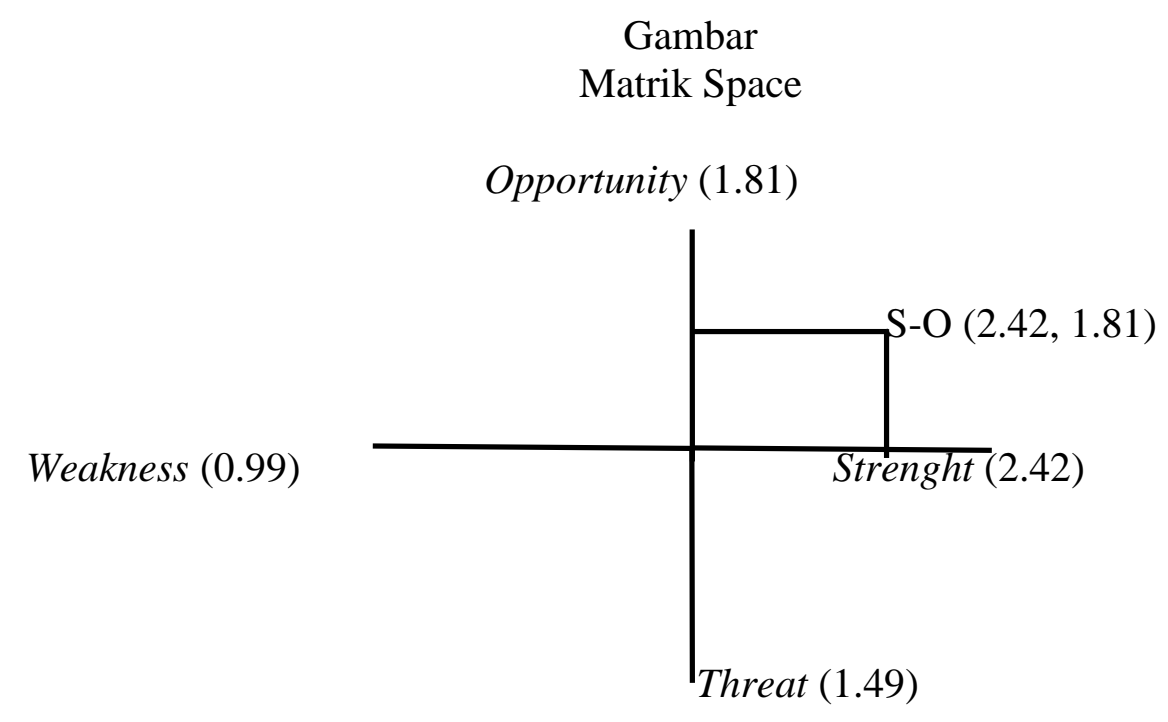

Untuk mengetahui strategi menangkal radikalisme agama di Kabupaten Sumbawa Barat, maka perlu dibuat matriks space. Berdasarkan tabel IFAS dan EFAS dapat dihitung sebagai berikut; Kekuatan (Strengths) - Kelemahan (Weaknesses) $=2,42$ $-0.99=1,41$. Sementara Peluang $($ Opportunities $)-$ Ancaman $($ Threats $)=1.81-1.49=$ 0.31. Merujuk data hasil analisis SWOT menunjukkan bahwa strategi menangkal radikalisme agama di Kabupaten Sumbawa Barat, adalah strategi S-O (StrengthsOpportunity) yaitu strategi yang memanfaatkan kekuatan yang ada untuk meraih peluang yang dimiliki.

\section{Strategi Menangkal Radikalisme Agama di Kabupaten Sumbawa Barat}

Berdasarkan hasil analisis SWOT (IFAS \& EFAS), maka strategi menangkal radikalisme agama di Kabupaten Sumbawa Barat adalah strategi S-O (StrengthsOpportunity) yaitu strategi yang memanfaatkan kekuatan yang ada untuk meraih peluang yang dimiliki, yang terdiri atas beberapa strategi berikut sebagai berikut:

Meningkatkan/Mengoptimalkan Peran Pemerintah, TNI, Polri, Tokoh Masyarakat dan Tokoh Agama dalam Melakukan Kegiatan Kebangsaan dan Cinta Pancasila.

Strategi ini dipilih untuk mengoptimalkan kekuatan yang ada untuk memanfaatkan peluang. Keberadaan pemerintah daerah yang responsif, TNI yang humanis, Polri, tokoh agama serta tokoh masyarakat sangat penting untuk menjadi aktor utama dalam menangkal kemunculan paham radikal. Para aktor ini juga sangat 
memungkinkan dan berpeluang lebih besar mempengaruhi masyarakat manakala melaksanakan dan terlibat penuh dalam kegiatan kebangsaan dan kegiatan-kegiatan cinta Pancasila. Pemerintah Kabupaten Sumbawa Barat yang responsif melalui kebijakan menghidupkan masjid agar masyarakat mudah dibina, Komando Distrik Militer (Kodim) Sumbawa Barat yang sering turun ke bawah bersama masyarakat, Kepolisian Resor (Polres) Sumbawa Barat yang selalu meminta Bhabinkabtibmas untuk sholat berjamaah di masjid-masjid di Sumbawa Barat dalam rangka pengawasan terhadap kemunculan kelompok-kelompok radikal, Kementerian Agama Sumbawa Barat yang selalu mengundang semua kelompok-kelompok keagamaan setiap tahunnya untuk berdikusi masalah kehidupan keagamaan, Majelis Ulama Indonesia Sumbawa Barat, Ormas Nahdlatul Ulama, Muhammadiyah, dan Nahdatul Wathon serta pimpinan pondok pesantren yang aktif melakukan kegiatan-kegiatan kebangsaan, adalah strategi yang bisa ditingkatkan dan dioptimalkan dalam mencegah masuknya paham radikal di Sumbawa Barat.

Mengoptimalkan Peran Serta Komunitas Cinta Damai dan NKRI Untuk Meningkatkan Rasa Saling Menghormati dan Menghargai antar Umat Beragama

Strategi ini dipilih untuk memaksimalkan peluang melalui pemanfaatan kekuatan yang ada. Optimalisasi komunitas cinta damai dan NKRI tersebut bisa dilakukan dengan cara mulai mengidentifikasi komunitas-komunitas yang ada di Sumbawa Barat untuk bersinergi mendesain kegiatan-kegiatan kebangsaan dan cinta NKRI. Baik itu dilakukan kepada masyarakat luas maupun ke sekolah-sekolah, pondok pesantren dan lainnya. Di Sumbawa Barat terdapat beberapa komunitas yang bisa menjadi mitra pemerintah dalam meningkatkan rasa saling menghormati dan kegiatan cinta damai diantaranya; Komite Nasional Pemuda Indonesia (KNPI), Gerakan Pemuda Anshor, organisasi kemahasiswaan seperti Himpunan Mahasiswa Islam (HMI), Pergerakan Mahasiswa Islam Indonesia (PMII), Ikatan Mahasiswa Muhammadiyah (IMM), Organisasi Siswa Intra Sekolah (OSIS) serta lembaga sosial kemasyarakatan lain seperti Lembaga Penelitian dan Advokasi Masyarakat Desa (Legitimid), Socrates Sekongkang, Forum Masyarakat Adat, Yayasan Darussalam NTB, Sahabat Bumi, Lembaga Kesejahteraan Sosial Sumbawa Barat, Lembaga Pemerhati Sumbawa Barat, Komunitas Literasi Anorawi, Lembaga Adat Tana Samawa (LATS) Anorawi, Wahana 
Demokrasi Taliwang, Institute Demokrasi (IDE), Center for Research and Community Development (CRCD) Taliwang, dan lain sebagainya.

Menyiapkan Aturan dan Program Peningkatan Kegiatan Toleransi Keagamaan, Kebangsaan dan Pancasila

Strategi ini dipilih untuk meminimalisir ancaman dengan memanfaatkan kekuatan yang dimiliki. Sejauh ini pemerintah daerah sangat responsif dalam menjaga kondusifitas kehidupan keagamaan di Sumbawa Barat. Oleh karena itu, dalam rangka memperkuat kembali rasa cinta dan kebanggaan terhadap NKRI maka program peningkatan kegiatan toleransi keagamaan, kebangsaan dan pancasila mesti disediakan payung hukum yang lebih luas. Agar kesinambungan program dapat terus berjalan. Pemerintah daerah Sumbawa Barat pun melalui Kemenag Sumbawa Barat dan Majelis Ulama Sumbawa Barat telah melaksanakan program-program yang mendukung peningkatan toleransi keagamaan diantaranya mengundang ormas dan kelompok keagamaan sebagai sarana silaturrahmi antar ormas dan kelompok keagamaan sekaligus membahas program konkrit bagi toleransi, menyiapkan kegiatan rutin penguatan Islam Rahmatan lil a'lamaiin kepada seluruh siswa dan siswi SMA dan SMK se-Kabupaten Sumbawa Barat, dan lainnya.

\section{Kesimpulan}

Berdasarkan temuan dan hasil analisis yang diperoleh dalam penelitian ini, dapat disimpulkan bahwa kecenderungan munculnya paham radikal berbasis agama di Sumbawa Barat oleh kelompok keagamaan tertentu masih ada dan perlu diawasi. Beberapa faktor yang berpotensi memicu radikalisme agama di Kabupaten Sumbawa Barat antara lain; ketidakpuasan terhadap kebijakan pemerintah, lemahnya pengawasan pemerintah terhadap sekolah-sekolah yang terindikasi gerakan radikal, serta pemahaman keagamaan yang merasa paling benar dibandingkan kelompok lainnya. Faktor internal yang berasal dari dalam kehidupan masyarakat Sumbawa Barat berupa kekuatan adalah adanya dukungan kebijakan pemerintah daerah, peran Polri, TNI, masyarakat dan tokoh agama, rasa saling menghargai antar agama, serta kondisi sosial keagamaan yang kondusif. 
Adapun kelemahannya antara lain; pemahaman keagamaan yang tidak sempurna, kurangnya pemahaman kebangsaan dan Pancasila, masih adanya kelompok masyarakat yang eksklusif dan fanatik, serta kondisi ekonomi masyarakat yang miskin. Sementara faktor eksternal berupa peluang meliputi regulasi dan kebijakan pemerintah pusat, kegiatan peningkatan kebangsaan dan pancasila, serta adanya komunitas cinta damai dan cinta NKRI. Sementara ancaman yang harus selalu diwaspadai diantaranya adanya kelompok-kelompok Islam aliran keras, adanya sarana prasarana penyebaran paham radikalisme, masuknya kelompok-kelompok penyebar radikalisme, serta kekecewaan terhadap kebijakan pemerintah.

Sedangkan strategi menangkal radikalisme agama di Kabupaten Sumbawa Barat adalah strategi S-O (Strengths-Opportunity) yaitu strategi yang memanfaatkan kekuatan yang ada untuk meraih peluang yang dimiliki. Karena itu, strategi prioritas yang perlu dilakukan adalah meningkatkan/ mengoptimalkan peran pemerintah, TNI, Polri, tokoh masyarakat dan agama dalam melakukan kegiatan kebangsaan dan cinta Pancasila, mengoptimalkan peran serta komunitas cinta damai dan NKRI untuk meningkatkan rasa saling menghormati dan menghargai antar umat beragama, serta menyiapkan aturan dan program peningkatan kegiatan toleransi keagamaan, kebangsaan dan pancasila.

Berdasarkan hasil temuan pada penelitian, maka dapat disarankan agar pemerintah daerah semakin memperhatikan keadilan bagi segenap warganya, semakin mengintensifkan pengawasan dan pembinaan terhadap sekolah maupun lembaga pendidikan yang tidak menghormati simbol-simbol negara. Terakhir, semua pihak semakin bersinergi dan melibatkan masyarakat dalam melakukan pencegahan dini terhadap kemunculan paham keagamaan radikal. Dengan mengetahui faktor-faktor pemicu kemunculan paham radikal, diharapkan bisa menjadi dasar menyusun strategi yang efektif dalam menangkal masuknya paham radikal.

\section{Ucapan Terima Kasih}

Penulis menyampaikan terima kasih kepada Direktorat Riset dan Pengabdian kepada Masyarakat, Kementerian Riset, Teknologi dan Pendidikan Tinggi yang telah mendanai penelitian ini tahun anggaran 2018. Ucapan terima kasih juga penulis sampaikan kepada kolega saya Muhammad Nursan di Universitas Mataram yang telah membantu memperkaya analisis penelitian ini. 


\section{DAFTAR PUSTAKA}

Abegebriel, A. Maftuh \& A. Yani Abeveiro. Negara Tuhan: The Thematic Encyclopaedia. Yogyakarta: SR-Ins Publishing, 2004.

Baradat, Leon P. Political Ideologies Their Origins and Impact. New Jersey: PrenticeHall, Inc, 1994.

Fanani, Ahmad Fuad. "Fenomena Radikalisme di Kalangan Kaum Muda" dalam Jurnal Maarif, Vol. 8, No. 1 (2013), h. 4-13.

Farikhatin, Anis. "Membangun Keberagamaan Inklusif-Dialogis di SMA PIRI I Yogyakarta" dalam Jurnal Maarif, Vol. 8, No. 1 (2013), h. 109-131.

Hasan, Noorhaidi. "Memahami Radikalisme Islam" dalam Paper Workshop Membangun Kesadaran dan Strategi dalam Menghadapi Gerakan Radikalisasi Agama, Depok, 19 Desember (2011).

Ilyas, Mohammad Syairozi Dimyathi \& Fatihunnada. "The Role of Religious Institutions in Preventing Radical Leftism" dalam Proceedings of the 2nd International Conference on Islam, Science and Technology-ICONIST (2019).

Imansari, Nitra Galih. "Peran Ulama Nahdlatul Ulama dalam Menangkal Radikalisme di Provinsi Jawa Timur". Tesis. Surabaya: Pascasarjana UIN Sunan Ampel, 2019.

INFID. Urgensi dan Strategi Efektif Pencegahan Ekstrimisme di Indonesia. Jakarta: INFID, 2018.

Kafid, Nur. "Ma'had sebagai Role Model De-radikalisasi" dalam DINIKA Journal of Islamic Studies, Vol. 13, No. 2 (2015), h. 21-33.

Kartodirjo, Sartono. Ratu Adil. Jakarta: Sinar Harapan, 1985.

Kosim, Mohammad. "Pesantren dan Wacana Radikalisme" dalam Karsa, Vol. 9, No. 1 (2006), h. 842-853.

Loveita, Lola. Radikalisme Agama di Indonesia: Urgensi Negara Hadir dan Kebijakan Publik yang Efektif. Background Paper 01. Jakarta: INFID, 2017.

Maarif, Ahmad Syafii. "Radikalisme, Ketidakadilan, dan Rapuhnya Ketahanan Bangsa" dalam Jurnal Maarif, Vol. 5, No. 2 (2010), h. 147-158.

Miles, Matthew B. \& A. Michael Huberman. Analisis Data Kualitatif. Jakarta: UI Press, 1992. 
Mubarak, M. Zaki. "Dari Semangat Islam Menuju Sikap Radikal: Pemikiran dan Perilaku Keberagamaan Mahasiswa UIN Syarif Hidayatullah" dalam Jurnal Maarif, Vol. 8, No. 1 (2013), h.192 -217.

Muhtarom, Ali. "Peran Ulama dalam Menangkal Radikalisme Agama di Kabupaten Batang Jawa Tengah" dalam RISTEK: Jurnal Riset, Inovasi dan Teknologi Kabupaten Batang, Vol. 1, No. 1 (2016), h. 45-65.

Muin, M. Abd, dkk. Pendidikan Pesantren dan Potensi Radikalisme. Jakarta: CV. Prasasti, 2007.

Munzir. "Identifikasi Isu Radikalisme di Pesantren Salafi" dalam Kalam, Vol. 7, No. 1, (2019), h. 41-54.

Rangkuti, Freddy. Analisis SWOT: Teknik Membedah Kasus Bisnis. Jakarta: Gramedia Pustaka Utama, 2006.

Ruslan, Idrus. Reorientasi Fungsi Lembaga-Lembaga Keagamaan dalam Meningkatkan Perilaku Umat Beragama yang Inklusif: Studi Terhadap MUI, PGI, PHDI dan Walubi Provinsi Lampung. Lampung: Pusat Penelitian dan Penerbitan LP2M IAIN Raden Intan Lampung, 2014.

Ruth, Dhyah Madya (Ed.). Memutus Mata Rantai Radikalisme dan Terorisme. Jakarta: Lazuardi Birru, 2010.

Salim, Agus. Teori dan Paradigma Penelitian Sosial: Buku Sumber untuk Penelitian Kualitatif. Yogyakarta: Tiara Wacana, 2006.

Saputra, Rangga Eka. Api dalam Sekam: Keberagamaan Generasi Z (Convey Report). Jakarta: Pusat Pengkajian Islam dan Masyarakat (PPIM) UIN Syarif Hidayatullah, 2018.

Sugiyono. Memahami Penelitian Kualitatif. Bandung: Alfabeta, 2012.

Takwin, Bagus dkk. Studi tentang Toleransi dan Radikalisme di Indonesia: Pembelajaran dari 4 Daerah Tasikmalaya, Jogjakarta, Bojonegoro dan Kupang. Jakarta: INFID, 2016.

Tim Penyusun Pusat Pengembangan Bahasa. Kamus Besar Bahasa Indonesia. Jakarta: Depdikbud \& Balai Pustaka, 1998.

Wahid Foundation. "A Measure of The Extent of Socio-Religious Intolerance and Radicalism within Muslim Society in Indonesia" dalam National Survey Report, March-April, 2016. 
Zaimah. "Strategi Menangkal Radikalisme melalui Pembelajaran PAI di Sekolah Dasar Islam Terpadu (SDIT) Assalamah, Bandarjo, Kec. Ungaran Barat,Kab. Semarang". Tesis. Semarang: Pascasarjana UIN Walisongo, 2019.

Zarkasyi, Jaja \& Thobib Al-Asyhar. Radikalisme Agama dan Tantangan Kebangsaan. Jakarta: Direktorat Jenderal Bimas Islam Kemenag RI, 2014.

\section{Website}

Kobarksb.com. "Sumbawa Barat Rawan Disusupi Paham Radikal" dalam https://kobarksb.com/bumi-paleba/sumbawa-barat-rawan-disusupi-pahamradikal/ diakses 16 Juni 2018.

Mutohar, Agus. "Radikalisme di Sekolah Swasta Islam: Tiga Tipe Sekolah yang Rentan" dalam http://theconversation.com/radikalisme-di-sekolah-swastaislamtiga-tipe-sekolah-yangrentan96722 diakses 25 Desember 2019.

Radarlombok.co.id. "NTB Hilangkan Stigma Daerah Radikalisme" dalam https://radarlombok.co.id/ntb-hilangkan-stigma-daerah-radikalisme.html diakses 20 Desember 2019.

Suarantb.com, "Bupati KSB Ungkap Gelagat Intoleransi di KSB" dalam https://www.suarantb.com/pilihan.editor/2017/239577/Bupati.KSB.Ungkap.Gel agat.Intoleransi.di.KSB/ diakses 20 April 2020.

\section{Wawancara}

Ustadz AAF, Sekretaris Pengurus Cabang Nahdlatul Ulama Kabupaten Sumbawa Barat, wawancara, 9 Juni 2018.

Ustadz MI, Majelis Ulama Indonesia Kabupaten Sumbawa Barat, wawancara, 7 Juni 2018.

Ustadz US, Kementerian Agama Kabupaten Sumbawa Barat, wawancara, 6 Juni 2018. 